\title{
Silver-coated monolitic silica column for separation of benzo[a]pyrene from petroleum
}

\author{
Vilius Poškus*, \\ Vida Vičkačkaitè, \\ Justina Rokaitè \\ Department of Analytical \\ and Environmental Chemistry, \\ Vilnius University, \\ 24 Naugarduko Street, \\ 03225 Vilnius, Lithuania
}

\begin{abstract}
Monolithic silica solid-phase extraction column has been successfully applied for the rapid fractionation and subsequent gas chromatographic analysis of benzo[a]pyrene from the diesel and oil matrix. Due to $\pi-\pi$ electronic interactions between silver nanoparticles on the sorbent surface and aromatic analyte specific retention was achieved. It was demonstrated that only $0.2 \mathrm{~g}$ of the sorbent and $6 \mathrm{ml}$ of the organic solvent are enough for such separation.
\end{abstract}

Keywords: solid phase extraction, silver nanoparticles, monolithic sorbent

\section{INTRODUCTION}

Sample preparation for the determination of trace concentrations of analytes in complex matrices usually includes two steps: extraction of an analyte or analytes from the matrix, followed by their purification [1].

This paper describes a novel procedure for the determination of benzo[a]pyrene in $\mathrm{C} 10-\mathrm{C} 40$ petroleum fractions. Polycyclic aromatic hydrocarbons (PAHs) have been classified as cancer-causing agents by the International Agency for Research on Cancer and the United States Environmental Protection Agency (US EPA), on the basis of evidences derived from studies in humans, experimental animals and other relevant data [2-4]. According to the carcinogenicity classification of 16 PAHs by the US EPA, benzo[a]pyrene is the most dangerous chemical among them. Because of this, benzo[a] pyrene is frequently sought as an indicator of PAHs contamination [3].

According to J. Cvengroš, T. Liptaj and N. Pronayova [5], the PAH content in a new motor oil is

\footnotetext{
${ }^{*}$ Corresponding author. E-mail: vilius.poskus@chgf.vu.lt
}

relatively low, but increases with motor operating time. The benzo[a]pyrene content of new motor oil can be up to $0.266 \mathrm{mg} / \mathrm{kg}$ but that of used motor oils from petrol cars can be up to $216 \mathrm{mg} / \mathrm{kg}$, i.e. almost 1000 times higher. This is caused by accumulation of the PAH from fuelled petrol and especially of the $\mathrm{PAH}$ formed during imperfect fuel combustion.

Various procedures for the fractionation of petroleum into aliphatic, aromatic, and other hydrocarbon groups were reported in the previous research [6-8]. These procedures include column liquid chromatography with various stationary phases, such as silica [7-11], alumina [6, 12], a combination of silica and alumina [13-15]. Thin layer chromatography [16, 17, and high performance liquid chromatography [18] can also be employed for such fractionation. These methods are often complicated and time-consuming. Also they generally require pre-treatment, cleaning, preparation, and activation of adsorbent packing materials.

Solid phase extraction (SPE) is a well-established technique used to separate many different classes of compounds in a variety of matrixes. Commercial SPE cartridges might be a possible alternative for 
developing a rapid, inexpensive and reproducible method. The SPE technique was recently used to improve fractionating of petroleum fuel due to its selectivity, faster elution profile, and minimization of solvent consumption [19-22].

Another attractive alternative for conventional sorbents is monolithic materials. They possess some unique features such as ease of fabrication, high surface area that enhances interactions with the analytes and thus separation efficiency, greater (through-pore size)/(skeleton size) ratios than conventional particle-packed columns (1-2 versus $0.25-0.4$ ), resulting in higher permeability in comparison with particulate columns with a similar number of theoretical plates [23]. For the specific interaction monolithic sorbents should be modified in order to tune their surface properties. Metallic nanoparticles profit excellent extraction for complex organic compounds such as proteins, aromatic organics (particularly given the $\pi-\pi$ electronic interactions that are established), and analytes containing amino and thiol groups [24].

Because of a high accessibility and high stability, monolithic mesoporous silica seems to be an ideal host for silver nanoparticles (Ag NPs) [25, 26. By now, only a very limited number of studies have been reported on the application of monoliths modified with metallic Ag NPs [25, 26-29]. The first monoliths containing Ag NPs described in 2011 contained physically immobilized Ag NPs [27]. Later on, monolithic sorbents containing covalently attached Ag NPs have been suggested [25-27, 29, 30].

It seems that silver nanoparticles confined in the porous structure are reasonably active and can be reused for many times. However, to the best of our knowledge, Ag NP modified monoliths have not been used for SPE of aromatic hydrocarbons, from petroleum matrix.

In this context, the goal of this research was to develop a rapid and simple method for separation of benzo[a]pyrene from petroleum matrix based on Ag NP modified silica monolith.

\section{EXPERIMENTAL}

\section{Reagents and solutions}

All the reagents were of analytical grade. Silver nitrate was obtained from Girochem (Slovenia). Acetic acid (99.7\%), toluene (99.5\%), (3-aminopropyl) triethoxysilane (APTES) (98\%) and tetramethoxysilane (TMOS) (98\%) were purchased from Alfa Aesar (USA), silver standard $\left(10 \mu \mathrm{g} \mathrm{ml}^{-1}\right)$ solution in $5 \% \mathrm{HNO}_{3}$ was purchased from PerkinElmer (USA). Ethanol (99\%), formaldehyde solution in water (37\%), decane (99\%) and tetracontane (98\%) were obtained from Sigma-Aldrich (Germany), Dichloromethane (99.9\%) was purchased from Merck (Germany), benzo[a]pyrene was obtained from LGC Standards (United Kingdom), and a mixture of diesel and oil 1:1 was purchased from BAM standart (Germany).

\section{Instrumentation}

The chromatographic analysis was performed on a Shimadzu GC-2010 plus gas chromatograph equipped with an AOC-20i auto injector and a flame ionisation detector. The GC system was equipped with a ZB-1HT (100\% dimethylpolysiloxane) capillary column $(15 \mathrm{~m} \times 0.32 \mathrm{~mm}, 0.1 \mu \mathrm{m})$.

\section{GC conditions}

Helium was employed as carrier gas with a linear velocity of $37.7 \mathrm{~cm} \mathrm{~s}^{-1}$. The injector temperature was held at $350^{\circ} \mathrm{C}$. Injection was performed in a split mode. The split ratio was 10:1. The oven temperature was programmed as follows: $50^{\circ} \mathrm{C}$ for

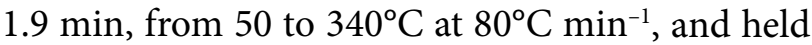
at $340^{\circ} \mathrm{C}$ for $5 \mathrm{~min}$. The flame ionisation detector temperature was held at $350^{\circ} \mathrm{C}$. Helium gas was used as make up gas at a flow rate of $30 \mathrm{ml} \mathrm{min}^{-1}$. The hydrogen flow rate was $40 \mathrm{ml} \mathrm{min}^{-1}$, and the air flow rate was $400 \mathrm{ml} \mathrm{min}^{-1}$. The signal acquisition rate was $40 \mathrm{msec}$.

\section{Synthesis of monolithic silica}

Silica monolith was synthesised according to [30]. In brief: $1.4 \mathrm{~g}$ of P123 was dissolved in $16 \mathrm{~mL}$ of $0.01 \mathrm{~mol} \mathrm{~L}^{-1}$ acetic acid on magnetic stirrer. After the complete dissolution of P123, the mixture was placed in an ice bath and kept stirring for $5 \mathrm{~min} .1 \mathrm{~g}$ of urea was added and fully dissolved. Then, $2.5 \mathrm{~mL}$ of TMOS was slowly added under vigorous stirring. The mixture was kept stirring until clear solution was obtained. The solution was transferred to $12 \mathrm{~mL}$ syringes. Air was removed, the syringes were closed and kept at $60{ }^{\circ} \mathrm{C}$ for $72 \mathrm{~h}$. The synthesised monolith was washed 2 times with $200 \mathrm{~mL}$ of distillated water and 1 time with $200 \mathrm{~mL}$ of water/ethanol solution (1:2) for $12 \mathrm{~h}$ per each time. After washing, 
the monolith was dried at room temperature for $24 \mathrm{~h}$ and at $40^{\circ} \mathrm{C}$ for 5 days. The monolith was removed from a plastic syringe housing and calcified using a temperature ramp rate of $1^{\circ} \mathrm{C} \mathrm{min}^{-1}$ up to $800^{\circ} \mathrm{C}$. It was kept at $800^{\circ} \mathrm{C}$ temperature for $5 \mathrm{~h}$.

\section{Modification of monolithic silica with aminopropyl groups}

Modification of the silica monolith with aminopropyl groups was accomplished according to [30]. In brief, $0.2 \mathrm{~g}$ of monolith was placed in $20 \mathrm{~mL}$ APTES/toluene solution $(4 \% \mathrm{v} / \mathrm{v})$ in a sealed amber glass tube. The mixture was stirred at $80^{\circ} \mathrm{C}$ for $2 \mathrm{~h}$ for the modification of the silica surface with aminopropyl groups. The modified monolith was washed with 3 portions of $20 \mathrm{~mL}$ of ethanol for at least $12 \mathrm{~h}$ per each time.

\section{Introduction of Ag NPs into aminopropyl groups modified silica monolith}

Introduction of Ag NPs into aminopropyl groups modified silica monolith was accomplished according to [30]. In brief, $0.2 \mathrm{~g}$ of the APTES modified monolith was immersed into $20 \mathrm{~mL} 0.1 \mathrm{M}$ ethanolic solution of silver nitrate for $48 \mathrm{~h}$ at room temperature. After, the sorbent was immersed into $10 \mathrm{~mL}$ of $37 \%$ formaldehyde solution for $1 \mathrm{~h}$. The resultant dark green-coloured monolith was washed with $20 \mathrm{~mL}$ of ethanol for 3 times and dried at $40^{\circ} \mathrm{C}$ for $72 \mathrm{~h}$.

\section{RESULTS AND DISCUSSION}

\section{Preparation of Ag NPs embedded monolithic silica}

Monolithic silica has been synthesised by employing the one-pot two-step reaction using TMOS as a precursor and catalysed by acetic acid (the first step) and the hydrolysis product of urea (the second step). A slow hydrolysis of urea into carbon dioxide and ammonia at $60^{\circ} \mathrm{C}$ leads to the base-catalysed polycondensation of TMOS and results in silica monolith formation. The synthesised monolith was calcified at $800^{\circ} \mathrm{C}$. After calcification, the monolith kept its cylinder shape, however its diameter strongly decreased (from 15.5 to $12.5 \mathrm{~mm}$ ). Figure 1 shows the morphology of the calcified silica monolith.

Further, the modification of the monolith with aminopropyl groups was achieved by the reaction of APTES and silanol groups of the monolith. The aminopropyl-grafted silica monolith was further treated with $\mathrm{AgNO}_{3}$ solution.

To obtain the Ag NPs modified silica monolith, silver ions had to be reduced to metallic silver. A lot of reducing agents for Ag NPs production is described in the literature including citric acid, ascorbic acid, glucose and $\mathrm{NaBH}_{4}$, formaldehyde [31-33]. In our case, only monolith-bound silver ions had to be converted to the metallic silver to form Ag NPs, meanwhile non-bound silver had to stay in a ionic form and be subsequently washed out. In our previous work, it was demonstrated that formaldehyde aqueous solution can be successfully applied for selective reduction of silver ions on a monolithic sorbent [30]. Based on this, we have applied formaldehyde to reduce sliver ions bonded to the aminopropyl groups modified monolithic sorbent. Figure 2 shows the photo and SEM image of the Ag NPs modified silica monolith.

\section{Separation of benzo[a]pyrene using Ag NPs embedded silica monolithic sorbent}

The prepared Ag NPs modified monolithic sorbent was tested for the separation of benzo[a]-

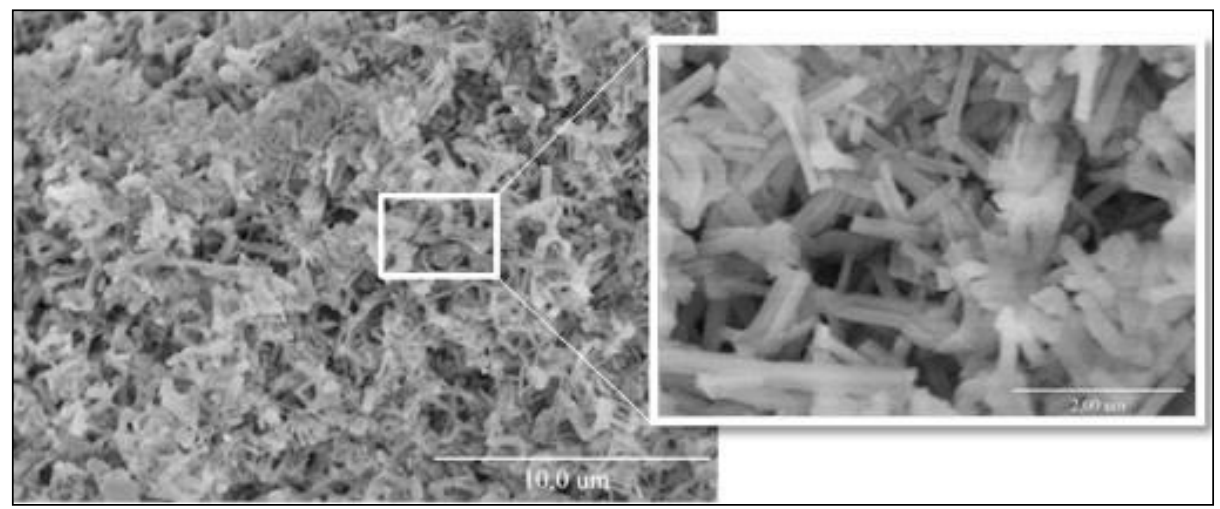

Fig. 1. The SEM image of silica monolith calcified at $800^{\circ} \mathrm{C}$ 


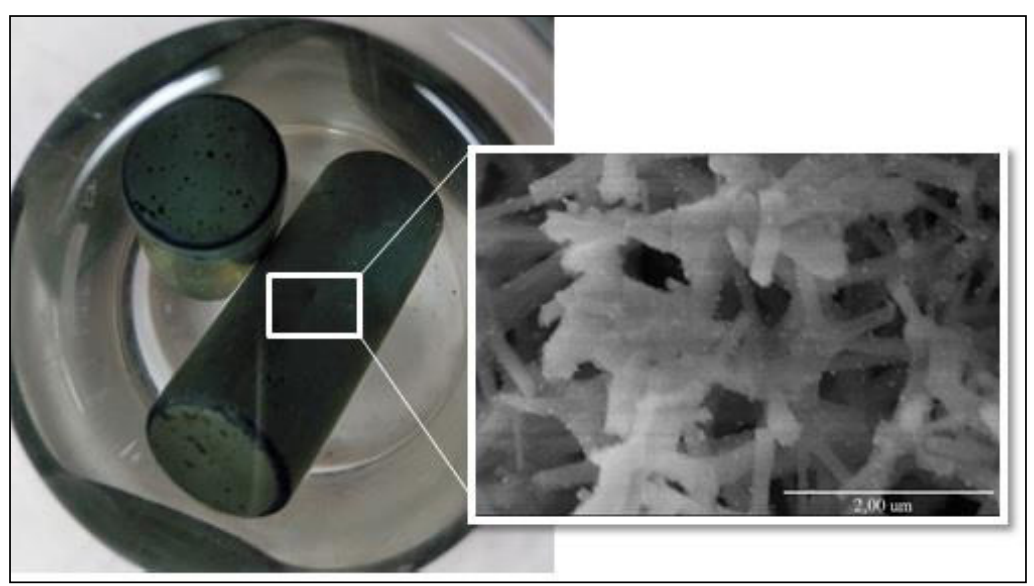

Fig. 2. The photo and SEM image of Ag NPs modified silica monolith. Coloured online

pyrene from aliphatic alkanes. The model solution of decane, tetracontane and benzo[a]pyrene (10 $\mathrm{mg} \mathrm{mL}^{-1}$ each) was used for this purpose. For the fractionation, $0.2 \mathrm{~g}$ of the sorbent was packed into a $2 \mathrm{~mL}$ syringe between glass frits. The sorbent was washed with $3 \mathrm{~mL}$ of hexane, then $50 \mu \mathrm{L}$ of the model solution was loaded onto the sorbent and six fractions ( $1 \mathrm{~mL}$ each) were collected and analysed on GC-FID. The separation conditions are described in the Table.

Alkanes were eluted from the column using n-hexane (1-2 fractions), meanwhile aromatic benzo[a]pyrene was retained. Elution of the analyte was achieved by increasing the polarity of the mobile phase. The third and fourth fractions were empty. Benzo[a]pyrene was collected in 5th and 6th fractions. Only $6 \mathrm{ml}$ of an organic solvent was used for the column elution to achieve the separation of an aromatic analyte from different carbon chain alkanes (Fig. 3). In order to optimise the separation method fractions containing the same components were combined. $2 \mathrm{ml}$ of hexane were needed for the alkanes elution (fraction 1), $2 \mathrm{ml}$ of $\mathrm{n}$-hexane: dichloromethane mixture $(95: 5 \mathrm{v} / \mathrm{v})$ were used to make a gap between the analyte (fraction 2), and $2 \mathrm{ml}$ of $\mathrm{n}$-hexane : dichloromethane mixture $(90: 10 \mathrm{v} / \mathrm{v})$ were needed for the elution of benzo[a] pyrene (fraction 3). A chromatogram of the model solution before and after fractionation is presented in Fig. 4.

Ta ble. Solid phase extraction steps using a silver nanoparticle modified monolith column

\begin{tabular}{cc}
\hline SPE step & Description \\
\hline Conditioning & Condition the column with $2 \mathrm{ml}$ of DCM, then $6 \mathrm{ml}$ of $\mathrm{n}$-hexane \\
\hline Sample load to the column & Apply $50 \mu$ l of sample with an analyte amount not exceeding $10 \mathrm{mg}$ \\
\hline 1-2 fractions & Elute with $1 \mathrm{ml}$ of $\mathrm{n}$-hexane \\
\hline 3-4 fractions & Elute with $1 \mathrm{ml}$ of $\mathrm{n}$-hexane $:$ dichloromethane mixture $(95: 5 \mathrm{v} / \mathrm{v})$ \\
\hline $5-6$ fractions & Elute with $1 \mathrm{ml}$ of $\mathrm{n}$-hexane $:$ dichloromethane mixture $(90: 10 \mathrm{v} / \mathrm{v})$ \\
\hline
\end{tabular}

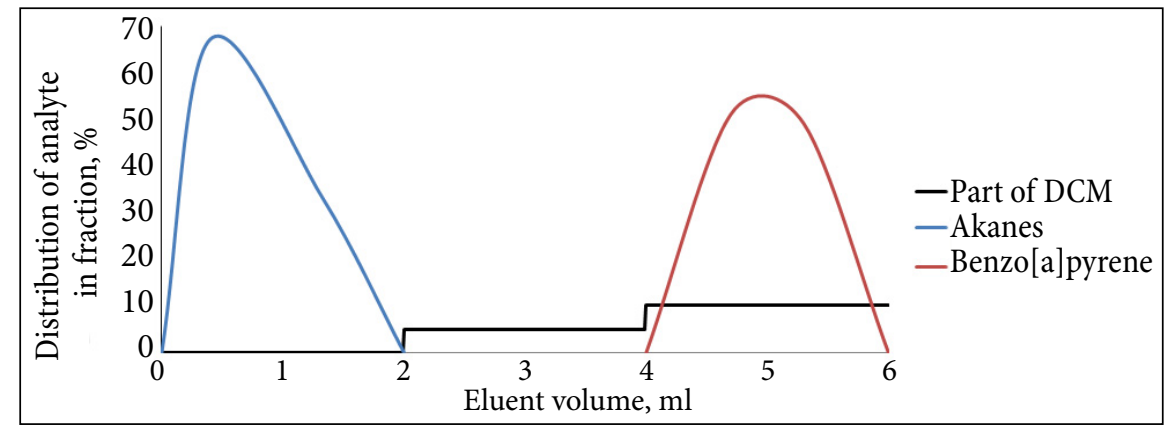

Fig. 3. The separation of aromatic analyte from different carbon chain alkanes. Coloured online 


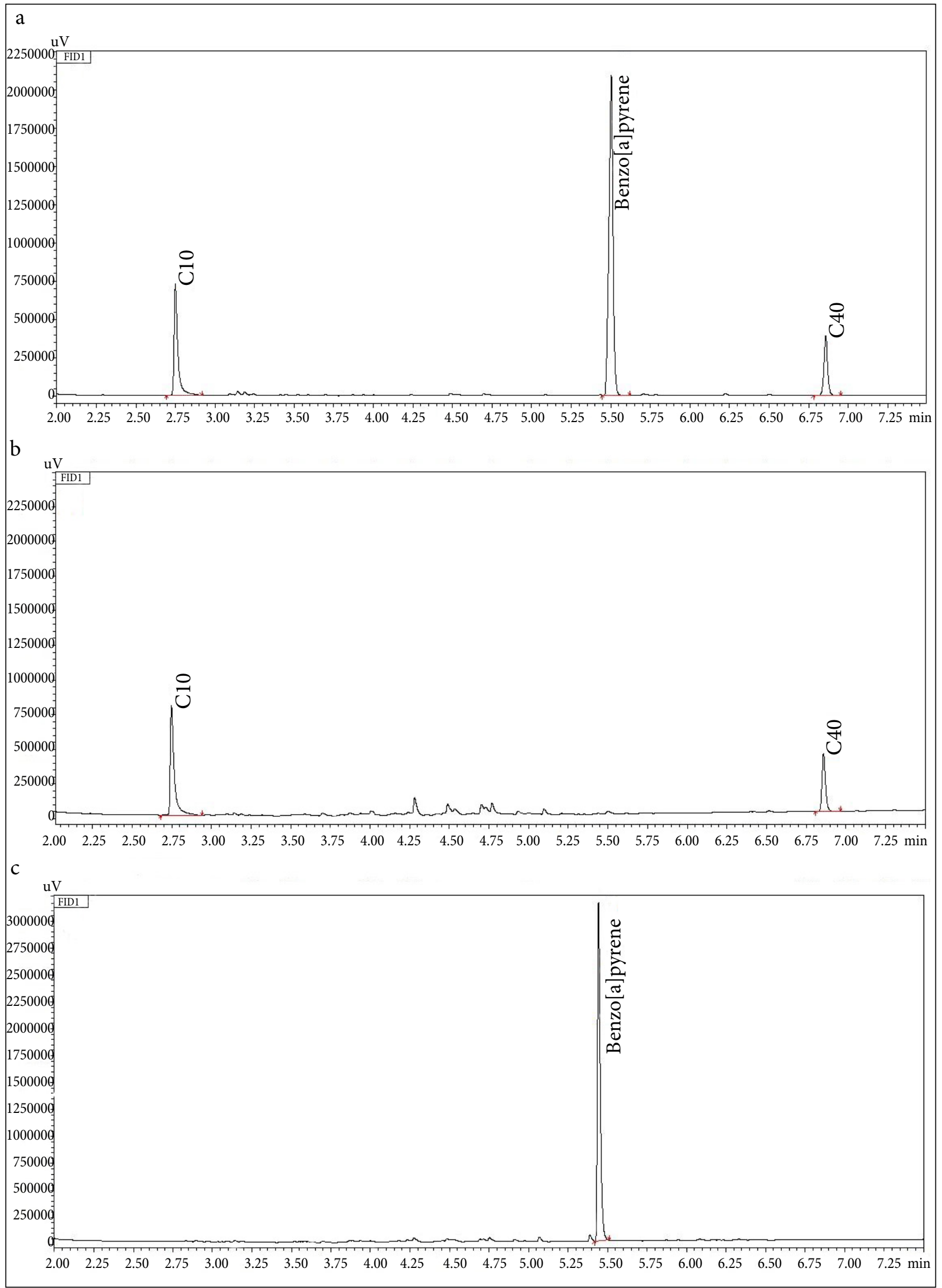

Fig. 4. The chromatogram of decane, tetracontane and benzo[a]pyreme mixture before fractionation (a), fraction 1 (b), fraction 3 (c) 


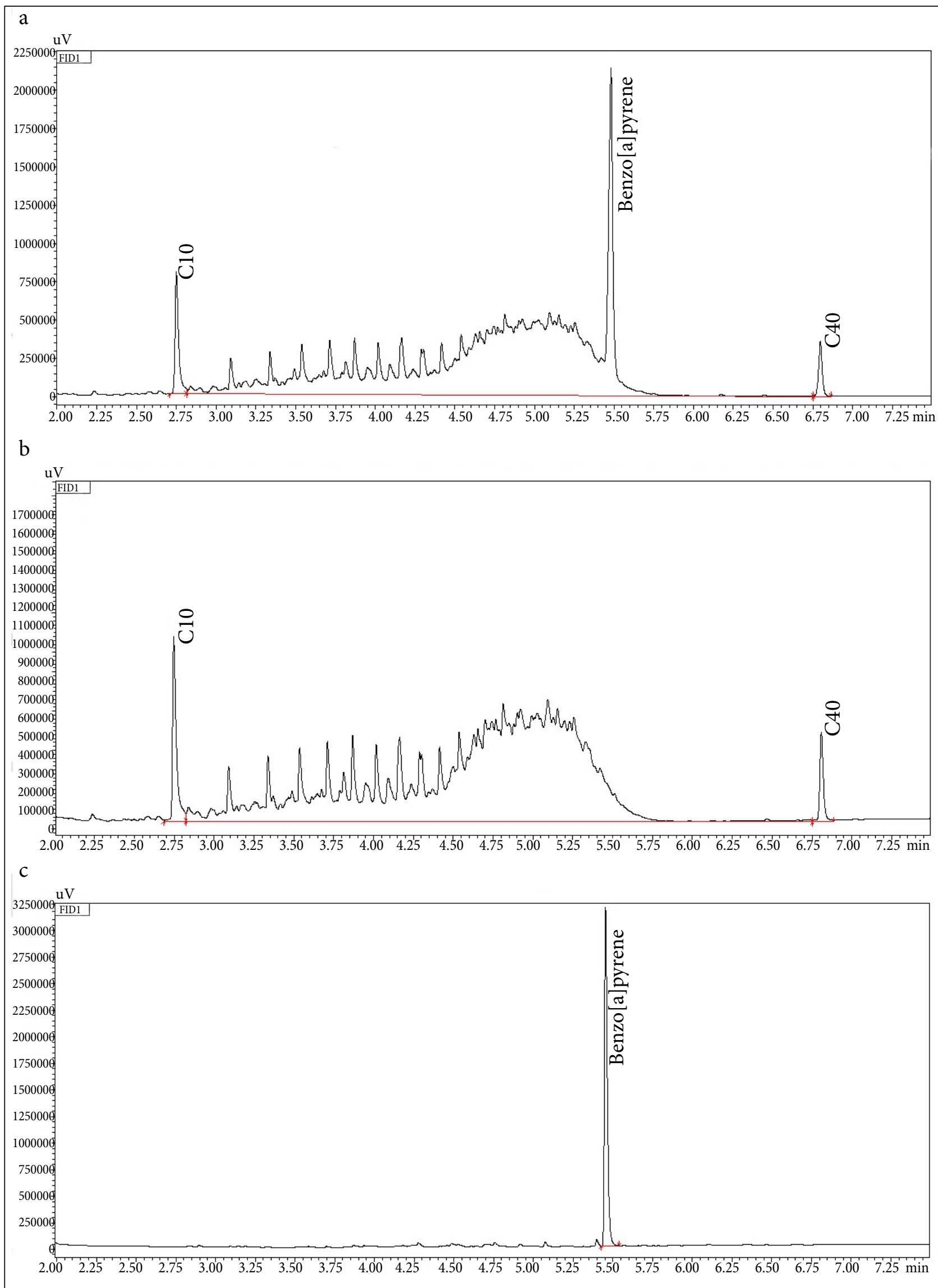

Fig. 5. The chromatogram of decane, tetracontane, diesel, oil and benzo[a]pyreme mixture before fractionation (a), 1 fraction (b), 3 fractions (c) 
The method was applied to a more complicated matrix. $10 \mathrm{mg} \mathrm{ml}^{-1}$ solution of diesel and oil in hexane was mixed with a solution of decane, tetracontane and benzo[a]pyrene in ratio $1: 1(\mathrm{v} / \mathrm{v})$. A chromatogram of this mixture before and after fractionation is presented in Fig. 5. The optimized elution technique was used for the fractionation. Decane, tetracontane and the mixture of diesel and oil was collected in the 1st fraction. Benzo[a]pyrene was eluted in the same fraction as in the previous experiment.

\section{CONCLUSIONS}

Silver nanoparticles embedded monolithic silica has been successfully synthesised and applied for the separation of benzo[a]pyrene from the diesel and oil matrix. Using the Ag NPs embedded sorbent, the full separation of an aromatic analyte has been achieved due to a specific interaction between silver nanoparticles and an aromatic compound. Only $0.2 \mathrm{~g}$ of a sorbent and $6 \mathrm{ml}$ of an organic solvent is enough for such separation. Since such system can fully separate different carbon length alkanes from an aromatic compound it could be used not only for pre-separation before GC analysis, but also for rapid preparative chromatography.

Received 23 February 2021 Accepted 15 March 2021

\section{References}

1. E. Gilgenast, G. Boczkaj, A. Przyjazny, M. Kaminski, Anal. Bioanal. Chem., 401, 1059 (2011).

2. EPA https://cfpub.epa.gov/ncea/iris2/chemicalLanding.cfm?substance_nmbr=136.

3. Polycyclic aromatic hydrocarbons (PAHs): sources, pathways and environmental data hittps://consult. environment-agency.gov.uk/++preview++/environment-and-business/challenges-and-choices user_uploads/polycyclic-aromatic-hydrocarbonsrbmp-2021.pdf.

4. T. Sanner, E. Dybing, D. Kroese, H. Roelfzema, S. Hardeng, Regul. Toxicol. Pharm., 23, 128 (1996).

5. J. Cvengroš, T. Liptaj, N. Pronayova, Int. J. Petrochem. Sci. Eng., 2(7), 219 (2017).

6. A. O. Barakat, A. R. Mostafa, Y. Qian, M. C. Kennicutt II, Spill Sci. Technol. Bull., 7, 229 (2002).

7. Z. Wang, M. Fingas, P. Lambert, G. Zeng, C. Yang, B. Hollebone, J. Chromatogr. A, 1038, 201 (2004).
8. C. Yang, Z. Wang, B. P. Hollebone, C. E. Brown, M. Landriault, J. Chromatogr. A, 1216, 4475 (2009).

9. P. Sun, B. Bao, G. Li, et al., J. Chromatogr. A, 1216, 830 (2009).

10. Z. Wang, M. Fingas, K. Li, J. Sep. Sci., 32, 361 (1994).

11. Y. Briker, Z. Ring, A. Iacchelli, N. McLean, Fuel, 82, 1621 (2003).

12. J. E. Schiller, D. R. Mathlason, Anal. Chem., 49, 1225 (1977).

13. D. W. Later, M. L. Lee, K. D. Bartle, R. C. Kong, D. L. Vassilaros, Anal. Chem., 53, 1612 (1981).

14. D. W. Later, B. W. Wilson, M. L. Lee, Anal. Chem., 57, 2979 (1985).

15. X. Gao, S. Chen, Estuar. Coast. Shelf Sci., 80, 95 (2008).

16. M. Kaminski, J. Gudebska, T. Gorecki, R. Kartanowicz, J. Chromatogr. A, 991, 255 (2003).

17. T. G. Harvey, T. W. Matheson, K. C. Pratt, Anal. Chem., 56, 1277 (1984).

18. C. A. Islas-Flores, E. Buenrostro-Gonzalez, C. Lira-Galeana, Energy Fuels, 19, 2080 (2005).

19. R. Alzaga, P. Montuori, L. Ortiz, J. M. Bayona, J. Albaiges, J. Chromatogr. A, 1025, 133 (2004).

20. B. Bennett, S. R. Larter, Anal. Chem., 72, 1039 (2000).

21. Z. Yang, C. Yang, Z. Wang, B. Hollebone, M. Landriaulta, C. E. Browna, Anal. Methods, 3, 628 (2011).

22. S. O. Alayande, N. Hlengilizwe, E. O. Dare, T. A. M. Msagati, A. K. Akinlabi, P. O. Aiyedun, Appl. Phys. A, 122, 392 (2016).

23. T. Ikegami, N. Takana, Annu. Rev. Anal. Chem., 9, 317 (2016).

24. K. Dastafkan, M. Khajeh, M. Ghaffari-Moghaddam, Trends Anal. Chem., 64, 118 (2014).

25. Y. Zhu, K. Morisato, W. Li, K. Kanamori, K. Nakanishi, Appl. Mater. Interfaces, 5, 2118 (2013).

26. Y. Zhu, K. Morisato, G. Hasegawa, et al., J. Sep. Sci., 38, 2841 (2015).

27. J. Liu, I. White, Don L. DeVoe, Anal. Chem., 83, 2119 (2011).

28. O. Sedlacek, J. Kucka, F. Svec, M. Hruby, J. Sep. Sci., 37, 798 (2014).

29. M. Vergara-Barberan, M. J. Lerma-Garcia, E. F. Simo-Alfonso, J. M. Herrero-Martinez, Microchim. Acta, 184, 1683 (2017).

30. V. Poškus, V. Vičkačkaite, Sep. Sci. Plus, 1, 738 (2018).

31. M. Manoth, K. Manzoor, M. K. Patra, P. Pandey, S. R. Vadera, N. Kumar, Mater. Res. Bull., 44, 714 (2009).

32. A. A. El-Kheshen, S. F. G. El-Rab, Der Pharma Chem., 4, 53 (2012).

33. Y. Qin, X. Ji, J. Jing, H. Liu, H. Wu, W. Yang, Colloids Surf., A, 372, 172 (2010). 
Vilius Poškus, Vida Vičkačkaitè, Justina Rokaitė

SIDABRU DENGTA MONOLITINĖ SILIKAGELIO KOLONĖLE் BENZO[A]PIRENO ATSKYRIMUI IŠ NAFTOS

Santrauka

Sèkmingai susintetintas ir aminopropilo grupèmis bei sidabro nanodalelèmis modifikuotas monolitinis silikagelio sorbentas pritaikytas benzo[a]pirenui išskirti iš tepalo ir dyzelio mišinio matricos. Kietafazès ekstrakcijos sistema dèl $\pi-\pi$ elektroninès sąveikos tarp sidabro nanodalelių sorbento paviršiuje ir aromatinès analitès specifiškai sorbuoja benzo[a]pireną ir visiškai nesąveikauja su nesočiaisiais angliavandeniliais. Parodyta, kad frakcionavimui pakanka $0,2 \mathrm{~g}$ sorbento ir $6 \mathrm{ml}$ organinio tirpiklio. 